\title{
Reconstructing Womanhood in Tony Morrison's Beloved
}

\author{
Setefanus Suprajitno
}

\begin{abstract}
Tony Morrison's fifth novel, Beloved (1987), explores the degradation of slavery imposed upon slaves, even when they were owned by a "humane" slave master. The novel is set in the Reconstruction period, the period after the American civil war. The word reconstruction may be used for the AfroAmericans, especially for the Afro-American women who face double discrimination for being black and women. In dealing with women's oppression, Afro-American women have to reconstruct themselves as an act of survival, and to be aware of the horrors of the experiences which their ancestors had to go through.
\end{abstract}

Keywords: reconstruction, womanhood, Toni Morrison, Beloved, Arfo-Amerivan.

In her works, Toni Morrison always employs and therefore preserves and perpetuates the cultural practices of Afro-American community. In an interview she tells Nellie McKay,

I'm not experimental, I am simply trying to recreate something out of an old art form in my books - the something that defines what makes a book "black." And that has nothing to do with whether the people in the book are black or not. The open ended quality that is sometimes a problematic in the novel form reminds me of the uses to which stories are put in the black community. The stories are constantly being retold, constantly being imagined within a framework. And I hook into this like a life-support system, which for me, is the thing out of which I come. (1983, p. 427)

That is why her works are deeply rooted in the black cultural tradition. Theodore Q. Mason even considers her as an example of a novelist as a conservator (1988). In her works Morrison tries to depict the cultural values of her society, that is, Afro-American society, and the way Afro-Americans preserve and maintain their identity. She admits that black self-determination motivates her in writing. She says

If my work is to confront a reality unlike that received reality of the West, it must centralize and animate information discredited by the West - discredited not because it is not true or useful or even of some racial value, but because it is information held by discredited people, information dismissed as "lore" or "gossip" or sentiment. (1984, p. 388)

Afro-Americans are often seen as the second class citizens in the American society. They are often discriminated and marginalized. Sydney Willhelm (1983) writes that Afro-Americans are now moving out of their historical state of oppressive slavery into that of uselessness. Racism and marginalization they face are the result of their structural position of redundancy and uselessness in the economic structure. Characters in Morrison's works often question themselves of reconstructing themselves in a 
defiance of a society which is constantly denying them their subjecthood. In the society they are often considered as ritualistic scapegoats, "exterior or marginal individuals, incapable of establishing or sharing the social bonds that link the rest of the inhabitant [of the society]. Their status as foreigners or enemies, their servile condition, or simply their age prevents these future victims from fully integrating themselves into the community" (Girard, 1977, p. 12).

Reconstructing one's psyche is difficult, hence reconstructing that of Afro-American women. This is so because of the devaluation of black womanhood which is "the result of the sexual exploitation of black women during slavery that has not altered in the course of a hundred years" (hooks, 1981, p. 53). And in Beloved (1987), Morrison shows us the Herculean task Afro-American women do, that is, reconstructing their selfhood.

Beloved talks about the degradation of slavery imposed upon all slaves, although they may belong to a master who is "human" and paternalistic, "[having] a special notion of duty and responsibility towards one's own charger" (Genovesse, 1994, p. 34). The setting of the novel is the period after the civil war in America (1861-1865), known as the reconstruction period in which nominally slavery ended. For Morrison, the word "reconstruct" can also be applicable to Afro-Americans, who are forced to reconstruct themselves as an act of survival.

Beloved is also put in a critical transitional point in the Afro-American history (1987, p. 53), which stresses the experiment of racism. Morrison herself says, "The trauma of racism is for the racist and the victim, the severe fragmentation of the self, and has always seemed to me a cause (not a symptom) of psychosis" (1989, p. 16). In Beloved, racism alienates both "the racist and the victim" - the Whites who systematically torture the slaves and conduct experiments on them to corroborate the prevailing hypothesis that they are more animal than human (Spillers, 1987) and in the process rendering themselves (the Whites) less human; and the Blacks who are tortured beyond endurance and therefore are forced to shut down part of their mind, or at least their memories in order to survive.

Beloved also reflects Morrison's desire in describing Afro-American experience in returning to their roots to create the "interior life" (Zinsser, 1987, p. 111 ) of slaves. Calling upon "memories and recollections" (p. 111), she explores and lays bare the stark reality of slavery, using a collate narrative technique of poetic prose. This resembles the process of "rememory," seeking to piece together the fragments of the past with its voices to form a coherent account of experiences previously denied in one way or another. The act of rememory is Sethe's main preoccupation.

Beloved also talks ancestry and relationships between the enslaved and the free, alive and dead, mothers and daughters. Beloved, the dead child who comes back to haunt her mother, has multiple symbolic meanings. She represents many African women whose stories are never told, and who are uprooted from their homeland to be enslaved, degraded, raped, and denied of identity by white men. She is also the haunting symbol of generations of mothers and daughters hunted down and stolen from their homeland.

Beloved is also rooted in a particular story and embodies members of Sethe's family. As Sethe's mother, she comes from the other side of the world, Africa; and as Sethe's daughter, she comes from the other side of life, death. Both historicize the "sixty million and more" (the epigraph to Beloved) slaves' experiences of sun-slit days in the hull of the ship with thirst and crouching death through the Middle passage, the transfer of slaves from Africa to the Caribbean across the Atlantic ocean. 
Sethe's nameless mother, like Beloved and Sethe herself, has been cruelly separated from her own mother. But in Ohio, 1873 , Sethe barely remembers her mother:

Of that place where she was born ... she remembered only songs and dance. Not even her own mother, who was pointed out to her by the eight-year-old child who watched over the young ones- pointed out as the one among many backs turned away from her, stooping in a watery field. Patiently Sethe waited for this particular back to gain the row's end and stand. What she saw was a cloth hat as opposed to a straw one, singularity enough in that world of cooing women each of whom was called Ma'am. (Morrison, 1987, p. 30)

Sethe, however, has one memory of her mother and that she was marked (p. 61). She does not know why her mother was hanged. Probably Ma'am was caught when she was trying to escape from the plantation, but the daughter born in bondage refused to believe that her mother could have run off as that would mean that she left her daughter, Sethe, behind, emphasizing the continuous pattern of severe mother-daughter relationships. Conceived with a Black man in love rather than with a White master through rape, Sethe, named after her father, was the only child her mother allowed to survive (p. 62).

In line with the central concern with history and memory, there is a compelling emphasis in the novel upon the survival of women within and beyond the structure of slavery, which is the source of the dominant emotions of intense grief and outrage in the Blacks' life, an existence "suspended between the nastiness of life and the meanness the dead" (p. 4) in which "not a house in the country ain't packed to its rafters with some dead Negro's grief" (p. 50). Slaves are like pieces of checkers and merchandizes, and they historicize the inhumanity of slavery. They recreate the "ad hoc" (Angelo, 1989, p. 49) black universe as a by-product of the "screaming baboons [living] under [the] white skins (Morrison, 1987, p. 214). This "ad hoc nature of everyday life" arises from the fact that "anybody might do anything at any moment" (Angelo, 1989, p. 49) to black slaves. There is, thus, no sense of certainty in the life of the slaves. This traumatizes the Blacks psychologically and accounts for their double-vision view of life, their radical extreme of loving to the extent of killing their own kind and its opposite of loving "small" (Morrison, 1987, p. 199) to preclude deep hurt when the loved ones are taken from them or vice versa.

124 Bluestone Road houses the history of the psychological effects of slavery on AfroAmerican women, being "a roaring" of black girls who [have] lost their ribbons" (p. 222). It is a metaphor of psychic imprisonment, presided over by the ghost of the burdened past, imaged in the spirit-character, Beloved. The psychic fence of 124 Blue Stone Road is staked by the belief that "anybody white could take your whole self for anything that come to mind .... Dirty you so bad you forget who you were and couldn't think it up" (p. 308), a double-edged sword curbing the inhabitants' power to imagine a future for themselves while locking them in a self-annihilating slave past. For Sethe, the future lies in "beating back the past" (p. 90), having been traumatized by Schoolteacher's form of slavery which reduces human parts to merchandize, plants the white jungle of chokecherry treed scars on her back and steals her nourishment for her children, slamming home the brutal truth of slavery as total ownership of body and soul. She suffers from the inability to separate "remembered" truth of slavery from reality, not knowing "where the world [stops] and she [begins]" (p. 202). Robbed by slavery of a center within her to anchor her self and tasting the freedom of "not [needing] permission for desire" (p. 199) at Ohio, Sethe moors herself in her children, her "best thing" (p. 308). Her attempt to kill them, succeeding with her "crawling-already (?) girl" (p. 187), is 
driven by motherly love which has displaced her self, and despair, imaged in the humming birds sticking their needle beaks into her hair and beating their wings ( $\mathrm{p}$. 200).

Sethe's drastic choice to kill Beloved rather than let her be returned to slavery shows that the bonds of mother and daughter, and the responsibilities they entail are proven with particular depth and complexity. What is shown is basically the relationships between mother and children which are characterized by uneasiness. Denver, Sethe's other daughter, fears her mother and so do her sons.

When Beloved comes back to haunt her mother, Sethe knows that what she thought was the best thing may not have been so from Beloved's point of view, and therefore in despair she asks Beloved to understand that she tried to kill her babies so that they would be protected from captivity forever, as being a slave meant that it would be impossible for her to be the kind of a mother she wanted:

Because the truth was simple and if she thought anything, it was No... Simple. She just flew. Collected every bit of life she had made, all the parts of her that were precious and fine and beautiful, and carried, pushed, dragged them through the veil, out, away, over there where no one could hurt them. (p. 53)

Beloved's response to Sethe is not only in the language of the murdered daughter, but also in the tortured language of the "woman from the sea." Murder and Middle Passage evoke the same language. They are the same existence, both were experienced by the multiple-identified Beloved, who is also the figure of both grief and outrage. She is grieved at being uprooted from her African culture and at the loss of identity as reflected in her desire to possess the face of the woman "[who] takes the flowers away from their leaves and put them in a round basket" (p. 261). This woman is later projected onto Sethe who represents the African past being the child of African parentage and carrying a name to bear witness to this heritage. Beloved is outraged by the denial of both her past and future on American soil by slavery. In her, the black voices of the past and present merge, resounding the cries for the "pain of being black" (Angelo, 1989, p. 49) and female.

Tony Morrison creates fluidity of identity among Sethe's grandmother, Sethe's mother, Sethe herself, and the murdered two-year-old, so that Beloved is both an individual and a collective being. She also functions as the crucial link that connects Africa and America for the enslaved women. Survival for Sethe meant keeping the past at bay. Remembering horrors of such enormous magnitude can cause a despair so profound that memories cancel out the possibilities of resolution or pleasure in the present and future. However, Morrison implies that even though memory of the past can prevent living in the present, to pursue a future without remembering the past has its own and even deeper despair for it denies the reality and sacrifice of those who died.

Since Beloved brings the whole traumatic experience of slavery with her, she not only knows more than she otherwise would have known in her previous short life, but she also contains the effects that slavery had - its profound fragmentation of the self (Morrison, 1987, p. 133), and the connections of the self might have had with others. Beloved is dislocated in time as well as within herself. All the incidentals and details of memory come down to the central affirmation that Beloved is her (Sethe's) daughter, as Sethe would have been a daughter to her own destroyed mother who left her. This restoration is thus not only of the return of her own child, but the restoration of herself as a child. Desperate to explain her action, memory becomes a path of explanation, and explanation a plea for forgiveness, capturing the ambivalent innocence and guilt in Sethe's moving narrative. 
In Beloved, Morisson seems to be more interested in "reconstructing" her women to be women, and not just mothers and daughters. In order to be women, they have to reclaim their voices (Greene, "Feminist Fiction"), to be able to talk back, which we find Sethe manages to do. She can tell her story, and in doing so, can claim herself. Such a speech becomes "a gesture of defiance that heals, that makes new life and growth possible. It is that act of speech of 'talking back,' that is no mere gesture of empty words, that is the expression of our movement from object to subject - the liberated voice" (hooks, 1991, p. 9).

\section{References}

Angelo, Bonnie. (1989). The Pain of being Black. Time (May 22, 1989). 48-50.

Genovese, Eugene D. (1994). The Southern tradition: The achievement and limitations of an American conservatism. Cambridge, MA: Harvard University Press.

Girard, Rene. (1977). Violence and the sacred. Trans. Patrick Gregory. Baltimore: John Hopkins UniversityPress.

Greene, Gayle. (1991). Feminist fiction and the uses of memory. Sign 16.2., 290-321.

hooks, bell. (1981). Ain't I a woman: Black women and feminism. Boston: South End Press.

........., (1989). Talking back. Boston: South End Press.

Mason, Theodore O. (1988) The novelist as a conservator: Stories and comprehension in Toni Morrison's Song of Solomon. Contemporary Literature. 29.4., 564-581.

Morrison, Toni. (1984). Memory, creation, and criting. Thought 59.235., 385-390.

, (1984). Memory, creation, and Writing. Thought 59.235., 385-390

, (1987). Beloved. New York: Alfred A. Knoff.

(1989). Unspeakable things unspoken: The Afro-American presence in American literature. Michigan Quarterly Review. 28, 1-34.

Spillers, Hortense J. (1987). Mama's baby, papa's maybe: an American grammar book. Diacritics 17,65-81.

Willhelm, Sydney. (1983). Black in a White America. Cambridge: Schenkman.

Zinsser, William. (1987). The Site of memory. Inventing the truth: The art and craft of memoir. Boston: Houghton Mifflin Company, 1987. 103-124. 